\title{
Review
}

\section{Levodopa-Induced-Dyskinesias Clinical Features, Incidence, Risk Factors, Management and Impact on Quality of Life}

\author{
Alice Manson ${ }^{\mathrm{a}}$, Paola Stirpe ${ }^{\mathrm{b}}$ and Anette Schrag ${ }^{\mathrm{b}, *}$ \\ ${ }^{a}$ Wessex Neurological Centre, Southampton General Hospital, Southampton, UK \\ ${ }^{\mathrm{b}}$ University College London, Institute of Neurology, Royal Free Campus, London, UK
}

\begin{abstract}
Levodopa-induced dyskinesias (LID) belong to the most common dose-limiting adverse effects of levodopa therapy. "Peak-dose" LID occur with the maximum effect of medication, "diphasic dyskinesias' have a "beginning- and end-of-dose" pattern, and the, "off-period dyskinesia" occur during off-periods, most frequently in the early mornings and are typically dystonic in nature.

The majority of patients will have developed dyskinesias after 10 years of treatment, and about $40-50 \%$ after 5 years. Occurrence of LID appears to be related to dose and duration of treatment with levodopa and severity and duration of disease. In addition, patients with younger age of onset have been reported to have an earlier onset and higher rate of LID. The important aetiological role of non-physiological pulsatile stimulation of dopaminergic receptors is increasingly recognized and more continuous dopaminergic stimulation with the longer acting dopamine agonists has been shown to reduce and delay the onset of dyskinesias. LID may not have a significant effect on quality of life in patients with early disease or in very advanced disease stages. when often other problems arise, but in other patients they may be severely disabling. Treatment strategies to overcome LID include adjustment of timing, type and amount of dopaminergic medication, treatment with amantadine and, in treatment resistant cases, stereotactic surgery involving deep brain stimulation or lesioning procedures. A number of other pharmacological options are also being explored. Several methods for the assessment of LID are available to attempt accurate assessment of efficacy, although all of these have limitations, and further evidence on their utility if needed.
\end{abstract}

Keywords: Dyskinesia, clinical features, epidemiology, treatment

\section{PHENOMENOLOGY}

Soon after the introduction of levodopa for the treatment of Parkinson's disease (PD) [1], it was noted that this treatment could be associated with undesirable, involuntary movements or 'dyskinesia' (derived from 'dys' difficult and 'kinesis' movement).

The most commonly recognized pattern of dyskinesia [2-4], are the peak-dose' dyskinesias. Muenter

*Correspondence to: Dr. Anette Schrag, MD, PHD, FRCP, Clinical Neurosciences, Institute of Neurology, Royal Free Campus, London NW3 2PF, UK. Tel.: +44 02077940500 x 36773; Fax: +44 0207472 6829; E-mail: a.schrag@ucl.ac.uk. et al. termed this pattern of dyskinesia the 'improvement - dystonia - improvement' or 'IDI' response, and established that it occurred around the time of peak plasma levels of medication [5], even though the severity of 'peak-dose' dyskinesias does not correspond well to plasma levels, suggesting a more complex mechanism to be involved in their generation $[3,6]$. Indeed, LID often occurs as a patient-specific 'all or nothing' response to adequate levodopa-dosing, and whilst their duration may be dose-responsive, it is also other factors such as emotional stress that affect severity [3, 7-9]. Peak dose LID are typified by usually generalized, choreiform type movements: i.e.: fleeting, 
non-rhythmic, purposeless fidgety-type movements. Often these are exaggerated by stress or activity and are typically asymmetric, being most prominent in the most affected side by the underlying disease [3, 9-11]. In addition to chorea, several other manifestations of peak-dose LID are seen: namely ballism (wild, proximal, flinging movements of the limbs), choreoathetoid (writhing-type) movements and more dystonic posturing (which will often begin in the lower limb or foot and herald the onset of the LID). Pure dystonic movements, although occasionally occurring as peakdose phenomena, are more often seen in the "wearingon' or '-off' phase or as an 'off'-period manifestation.

As well as the 'IDI' response, Muenter et al. also described a 'DID' (dystonia-improvement-dystonia) response, whereby patients would experience druginduced dyskinesia as the effects of levodopa were wearing on and off [12]. They noted that these dyskinesias affected predominantly younger patients and occurred when the concentration of levodopa in plasma passed through a critical but relatively low level, whereas it remained absent as long as the concentration remained above that level. As noted above, this type of dyskinesia is predominantly dystonic in character and, due to its occurrence at the onset and/or end of action of levodopa, is now more commonly referred to as 'diphasic' or 'biphasic' dyskinesia.

The third pattern of dyskinesia in levodopa treated patients with PD is that of 'off'-period dystonia. This is a recognized complication of drug therapy and is separate from the dystonia of untreated Parkinsonism: it commonly occurs early in the morning, and is often painful, distressing and disabling. It frequently affects the lower limbs but can involve any region such as facial, oral, lingual and even the laryngeal, respiratory and extra- ocular muscles $[4,9,13]$.

\section{INCIDENCE}

Estimation of rate of LID occurrence as a function of disease duration is difficult, partly due to the uncertainty of establishing the exact time of disease onset; in addition, dyskinesias only occur after antiparkinsonian treatment is started, with the exception of dystonia, which can occasionally occur in untreated PD [14]. Therefore latency from onset of treatment to onset of dyskinesias often provides a more useful measure. The frequency of LID in parkinsonian patients has been reported in several studies but the reported incidence varies greatly between them. Such differences may partly depend on different study methods, different selections of patients [15] and different patient populations (community-based or clinic-based) [2, 16], but partly also reflect differences in ascertainment if dyskinesias are not reported by patients, who are often unaware especially of mild dyskinesias [2, 17], and if dyskinesias are not present during a consultation.

It is widely accepted that it is rare $(<10 \%)$ to develop LID within the first year of treatment with levodopa, but reports vary from $0 \%$ [18] to $50 \%[15,19]$ of patients with dyskinesia in the first year of treatment.

In retrospective analyses in clinic-based samples dyskinesias were reported between $54 \%$ of patients at 6 years of levodopa therapy in one study [20] and in 56\% after a mean duration of 3 years [21]. In prospective randomized controlled trials (RCTs) approximately $40-50 \%$ of patients are found to develop LID after 5 years of treatment with levodopa [15, 22, 23].

In long term follow-up studies, the incidence of LID at 10 years of treatment with levodopa treatment was found in 52-78\% at 10 years [24, 25], and after 15 years $94 \%$ of survivors in the Sydney Multicentre study of PD had developed dyskinesia [26]. In a series of 42 patients with autopsy-verified PD dyskinesia was the most common and earliest complication, with a rate of $62 \%$ developing dyskinesia after an average of 10 years of levodopa treatment [27].

Thus, whilst there may be a small group of patients who never develop LID [30], it is largely accepted that dyskinesias occur almost inevitably at the later stages of PD.

\section{RISK FACTORS}

Typically, LID only occur in patients with a good response to levodopa, i.e. mainly in patients with idiopathic PD on an effective dose of levodopa, although patients with multiple system atrophy may develop severe, and usually atypical, LID early in the disease. As mentioned above, there also appears to be a dosedependence to the occurrence and severity of LID in $\mathrm{PD}$ and reduction in medication dose often improves or abolishes these [25, 31].

Dose and treatment duration have the strongest impact on dyskinesias prevalence [2]. For example, in the ELLDOPA trial $16.5 \%$ of patients randomized to $600 \mathrm{mg}$ of LD daily developed dyskinesias after only 9 months of treatment versus $2.3 \%$ among those on $300 \mathrm{mg}$ [32].

Although duration of treatment has been demonstrated to be an independent risk factor in generating LID [2, 33], it is possible that this, at least partly, also reflects disease duration [15, 19] and severity $[34,35]$, which has been shown to correlate highly 
with treatment duration as well as rate of dyskinesias $[2,36]$.

It has also been recognized that LID tend to be more severe and occur more frequently and sooner in younger onset (before the age of 50) patients [2, $33,37,38]$. The most statistically significant difference occurs between ages 40-49 and ages 50-79 and the increased risk of dyskinesia in patients with PD onset $<50$ appears to be concentrated in the first two years of L-dopa therapy $[15,39]$. Thus, in patients with onset of PD before age 40 years up to $90 \%$ have developed dyskinesias after 5 years of treatment, and up to $100 \%$ after ten years [40, 41], whereas LID represent a relatively infrequent problem in patients with an age at onset over 60 years (53\% in the 50-59 years of age onset group, 26\% risk in the 60-69 years group and $16 \%$ in the over 70 years group [38]. Even when accounting for different disease durations, age of onset remained a significant factor.

This relationship between age of onset and development of LID may be at least partly due to genetic influences [19]. Some forms of genetically determined Parkinsonism at young onset have been reported to have a higher risk of developing LID [2, 41-44], and a higher prevalence of dyskinesias has been reported in patients with a family history of PD than those without [2, 43].

In particular, PARK2 (parkin), PARK 6 (pink-1) and PARK 7 (DJ-1) mutations, which are associated with young-onset $\mathrm{PD}$, have been reported to have high rates of dyskinesia [45-47], and one study reported a higher risk of developing LID in LRRK2 parkinsonism compared to genetically undetermined PD [47, 48]. However, more recent studies reported that carriers of parkin or LRRK2 mutations did not have more LID than non carriers when matched for age and disease duration $[49,50]$.

Other genetic factors may also contribute to the variability in incidence, severity and latency from treatment onset, and result in different susceptibility to develop dyskinesia. For example, associations of occurrence of dyskinesias have been reported with polymorphisms in the dopamine receptor D2 and transporter gene [51], the TaqIA polymorphism located in the gene encoding the D2 receptor [52], the catechol-O-methyltransferase (COMT) gene [53] and the mu/opioid receptor gene [54], but not the APOE gene [55]. Additionally, a recent study found that a common functional polymorphism of the BDNF gene (val66met allele) was associated with a significantly higher risk of developing dyskinesias earlier in the course of treatment with dopaminergic agents [56], but the importance of these results at the present time is not yet clear and these need to be replicated in other and larger populations.

Other factors suggested to be associated with a higher risk for dyskinesia are history of never smoking [57], gender [58], and lower body weight [59] (although, as the latter did not clearly predate the onset of dyskinesia, the causality of this relationship is not established). A negative correlation between resting tremor as an initial manifestation of PD and LID occurrence and severity has also been reported [60].

\section{ASSESSMENT OF LID}

One of the challenges facing the clinician or researcher dealing with LID is their accurate assessment and purely objective quantitative measurement devices have clear limitations [61]. Several rating scales have been used in clinical practice, including scales relying on observations by a physician, patientkept diaries and questionnaires or scales combining these efforts.

However, the fluctuating nature of PD itself, the variability in the duration and severity of LID from day to day and even within the same day without any predictable pattern, and the lack of awareness of dyskinesias patients may represent considerable challenges to their assessment. Therefore, many trials use a complicated combination of these scales with video challenge, a more objective measure, in order to overcome these limitations [62].

An ideal instrument for dyskinesia assessment should be a single scale, able to capture patient perceptions, time factors of dyskinesia, anatomical distribution, objective impairment, and disability [63].

Recently, a systematic review by a task force of the Movement Disorders Society concluded that, among scales, the Abnormal Involuntary Movement Scale (AIMS) and the Rush Dyskinesia Rating Scale (RDRS) formally fulfill the criteria known as 'recommended', but both scales still have considerable limitations. The AIMS is a clinician-rated instrument to assess the severity of abnormal movements in different parts of the body. It was initially developed for the evaluation of tardive dyskinesia in psychiatric patients, but has been modified by several authors for its use in PD. The RDRS focuses on disability and the impact of dyskinesia on specific activities of daily living.

The task force however affirmed that two more recent scales (PDYS-26 and UDysRS) have excellent clinimetric properties and appear to provide a reliable and valid assessment tool of dyskinesia in PD 
of dyskinesia in PD. The Unified Dyskinesia Rating Scale (UDysRS) combines elements of the AIMS and RDRS into a single measure to assess both impairment and disability [64]; it contains a self-assessment by the patient as well as an examination by the physician. The PD Dyskinesia Scale-26 is a patient-based measure for quantifying the impact of dyskinesias on specific activities of daily living and quality of life of patients with PD [65]. However, these could only be considered "Suggested", requiring further clinimetric testing.

\section{MANAGEMENT OF LID}

The clinical challenge is to find, first, a method to delay the onset of dyskinesias, whilst adequately treating the parkinsonian symptoms and, secondly, a treatment strategy to minimise established LID without worsening Parkinsonism.

In order to delay the onset of dyskinesias clinicians may choose to use dopamine agonists in place of levodopa in de-novo patients as first-line therapy [66], particularly if they are young and are therefore at increased risk of developing this complication. Lees and Stern first noted that patients taking the agonist bromocriptine alone, tended not to develop the motor side effects associated with levodopa therapy [67]. Since then a number recent studies have demonstrated that starting treatment with other dopamine agonists, including pramipexole [22], ropinirole [68], ropinirole prolonged release [69], and cabergoline [70], is effective for prevention/delay of dyskinesias, findings which have been summarised in a recent review of evidence based studies [71]. However, it should be noted that it has recently been suggested that of the occurrence of severe, clinically troublesome LID occurs at the same stage whether levodopa treatment is delayed or not $[22,35]$. In addition there is increasing evidence that other factors reflecting advancing disease become more important at later stages and do not differ between those treated with levodopa and dopamine agonists [26, 72].

When LID have appeared, the simplest and most obvious strategy to reduce LID is to reduce the dose of dopaminergic therapy, but this almost inevitably leads to an unacceptable worsening of parkinsonian symptoms. It is widely believed that one of the major factors in promoting motor complications such as LID in $\mathrm{PD}$ is the artificial pulsatile dopaminergic stimulation which occurs as a result of pharmacological treatments [73] and thus more continuous dopaminergic stimulation is sought as a means of avoiding or minimizing these. This can include adjusting dopaminergic treatment with smaller single-doses in case of peakdose dyskinesia, or increased single-dose in patients with biphasic dyskinesia [73-75]. Many sustainedrelease preparations of levodopa have been employed but there is little evidence to show that this strategy is effective [8] and, in advanced PD with motor fluctuations, results from controlled studies suggest that $\mathrm{CR}$ preparations have a tendency to produce increasingly severe dyskinesias [76]. Therefore, for the management of peak-dose dyskinesias it may be helpful to replace controlled-release with immediate release of levodopa-carbidopa, which may be easier to adjust and duration of dyskinesias may be shorter [77]. Dopamine agonists have a longer duration of action and thus theoretically provide more continuous receptor stimulation. This can therefore be a useful strategy both for patients with dyskinesias as a 'dopa-sparing' technique with a smoothening of response. Strategies for providing continuous dopaminergic stimulation also include the administration of continuous subcutaneous infusions of the potent dopamine agonist apomorphine, which, particularly when used as monotherapy, can dramatically reduce established LID [78, 79] as well as direct intrajejunal infusion of Duodopa [80, 81]. However apomorphine and intrajejunal infusion of Duodopa are complex, require considerable patient and/or carer involvement, and are relatively expensive $[82,83]$. Although good long-term results with apomorphine have been demonstrated in some centres, others found a considerable dropout rate, mainly due to painful subcutaneous nodules and it showed an insufficient control of motor signs and motor complications in a 5 years follow-up study [84]. Duodopa treatment is associated with frequent complications of the gastrostomy procedure $[83,85]$ and has been linked to the axonal peripheral neuropathy [86, 87], and clinical trial data are sparse.

Other methods targeting the non-dopaminergic pathways to avoid interfering with control of other aspects of the disease are also being explored [88, 89]. Of these, the drug amantadine has been used to treat PD for many years but its anti-dyskinetic properties, which are thought to be mediated via its glutamate NMDA receptor antagonism, have only been well demonstrated fairly recently [90-94]. It is effective and relatively easy to use, but it can produce side-effects (mainly anticholinergic) which mean that it is not suitable for all patients and there is a rate of non responders, that seem be associated at younger age of onset [95, 96]. 
A different approach is to try to target the dopaminergic system selectively to reduce dyskinesias without worsening parkinsonism, and clozapine, an 'atypical' neuroleptic, has shown promise in this respect [97-99]. However, its potential side-effect profile means that it cannot be used routinely and unfortunately controlled trials of similar but less toxic drugs, such as olanzapine and quetiapine have not shown equal effect $[100,101]$.

Other non-dopaminergic pharmacological agents, which have been investigated, include agonists of 5HT1A receptor such as sarizotan [62], antiepileptic drugs as levetiracetam [102, 103], the adenosine A2A receptor antagonist preladenant [104] and safinamide [105], a potent, highly selective and reversible inhibitor of monoamine oxidase B (MAOB) and dopamine reuptake with antiglutamatergic effects. Further study is needed to evaluate their efficacy in minimizing the risk for dyskinesias. In addition, Fipamezole, a2adrenergic receptor antagonist, has been assessed, reporting a reduction in dyskinesia without worsening of parkinsonian symptoms in the MPTP-lesioned primate model of PD [106]. However, clinical studies with idazoxan, another a2-adrenergic receptor, showed conflicting results [107]. Perampanel, selective AMPA receptor antagonist, has also been assessed, without significant effect [108].

Finally, other promising non dopaminergic compounds in early stage of development are Pardoprunox [109], a partial agonist at D2 and D3 receptors and full agonist at 5 HT1 receptors, the $\alpha 4 \mathrm{~b} 2$ and $\alpha 6 \mathrm{~b} 2$ nicotinic subtype receptors [110] and the negative allosteric modulators of mGluR5 AFQ-056 and ADX48621 [111, 112].

Advances in knowledge of functioning of basal ganglia and in surgical techniques, lead to a reemergence of surgery PD in the last 25 years, directed mainly at advanced PD complicated by disability from motor fluctuations, dyskinesia, and tremor that are medically intractable [113, 114].

In recent years, DBS of GPi and STN have replaced largely lesioning techniques (thalamotomy, pallidotomy, or subthalamotomy), being largely reversible, without or minimal tissue damage, and allowing adjustment of settings according to clinical need [113, 115].

Studies showed that STN-DBS leads to a reduction of disabling dyskinesias by about $60 \%$ [116] and DBS of the GPi lead to an immediate reduction of levodopainduced disabling dyskinesias of about $80 \%$ [117].

A recent study comparing DBS of both the GPi and STN suggests that both targets might offer similar motor benefits [118], but that the use of dopaminergic medications decreased more for the STN DBS group than for the GPi DBS group. This difference may influence the DBS target chosen for patients. Thus, for some patients a reduction of medications may contribute to a better quality of life, for other a reduction may not be desirable [119].

In comparison, the best adjunctive medications developed in the last 25 years improve "off" time in PD by 1-2 hours, whilst DBS improves "off" time by 5-6 hours, allows a substantial reduction in medications in many patients, and often eliminates dyskinesias entirely [120].

Besides procedural surgical complications, such as hemorrhages or central nervous infections [121], complications of STN-DBS include cognitive side effects, such decreased fluency verbal, apathy, impulsivity, and postoperative depression [122-125]. Therefore, this treatment is mainly considered in patients without significant active cognitive or psychiatric problems [113].

Recently, also bilateral cerebellar rTMS has been reported to show persistent clinical beneficial effects in reducing peak-dose LID [126], but further study is needed to assess and refine the method.

\section{EFFECT OF LID ON QUALITY OF LIFE (QOL)}

It is clear that LID are disabling and carry with them significant co-morbidity especially when severe. Patients complain that they are socially embarrassing, and prevent or impede their daily activities including vital tasks such as eating and drinking, when they may be at their worst $[61,127]$. In addition, they are associated with weight loss [78], which can present a major problem in $\mathrm{PD}$, and other symptoms such as breathlessness and even vomiting [128]. Therefore one would expect LID to have a significant effect on QOL and some studies have reported worse QoL scores in patients with dyskinesias, particularly biphasic dyskinesias [129-131]. However, once confounding factors such as disease severity and treatment duration were accounted for, clinical studies have mostly failed to show such association between dyskinesias and poor QoL $[2,132]$. One explanation for this result could be that often dyskinesias are mild with little impact on daily living, whereas only a smaller group of patients with advanced disease have severe, disabling dyskinesia. In addition, if only patients with a good response to levodopa develop dyskinesia they would be expected to have a better quality of life than those receiving little anti-parkinsonian benefit from their medication [2]. 
This hypothesis is supported by results by Marras et al. who found that LID were associated with a better QOL in the first few years of treatment even after accounting for the difference in UPDRS scores of parkinsonism. In advanced disease, a proportion of patients have dyskinesias severe enough to require deep brain stimulation (DBS) surgery and in the subgroup with more severe, disabling dyskinesia these are associated with poorer QoL. However, after disease duration of more than 10 years, dyskinesias that are clinically relevant and require medication adjustments are often not the primary clinical concern $[26,28,29,133]$ and, despite the high rate of dyskinesias with longer follow-up, may therefore have less relative impact on patients' QoL in the overall population.

As the trend for more quality of life measures to be introduced into clinical trials continues, we will gain more information in the important area of improvement of overall QoL with treatment of dyskinesias, accounting for different disease variables and subgroup characteristics. This will help to ensure that improvement in objective rating ratings of dyskinesia severity are translated in subjective benefit for the patients.

\section{DISCLOSURES}

All the authors have contributed to the work and agree with the findings.

No financial support was received for this work and the authors have no financial interest in the views expressed.

\section{REFERENCES}

[1] Cotzias GC, Papavasiliou PS, \& Gellene R (1969) Modification of Parkinsonism chronic treatment with L-dopa. $N$ Engl J Med, 280, 337-345.

[2] Schrag A, \& Quinn N (2000) Dyskinesias and motor fluctuations in Parkinson's disease. A community-based study. Brain, 123, 2297-2305.

[3] Nutt JG (1990) Levodopa-induced dyskinesia: Review, observations, and speculations. Neurology, 40, 340-345.

[4] Fahn S (2000) The spectrum of levodopa-induced dyskinesias. Ann Neurol, 47(4 Suppl 1), S2-S9, discussion S9-S11.

[5] Muenter MD, \& Tyce GM (1971) L-dopa therapy of Parkinson's disease: Plasma L dopa concentration, therapeutic response, and side effects. Mayo Clin Proc, 46, 231-239.

[6] Manson AJ, Katzenschlager R, Hobart J, \& Lees AJ (2001) High dose naltrexone for dyskinesias induced by levodopa. J Neurol Neurosurg Psychiatry, 70(4), 554-556.

[7] Nutt JG (2000) Clinical pharmacology of levodopa-induced dyskinesia. Ann Neurol, 47(4 Suppl 1), S160-S164; discussion S164-S166
[8] Durif F (1999) Treating and preventing levodopa-induced dyskinesias: Current and future strategies. Drugs Aging,, 14(5), 337-345.

[9] Mones RJ, Elizan TS, \& Siegel G (1970) L-dopa induced dyskinesias in 152 patients with Parkinson's disease. Trans Am Neurol Assoc, 95, 286-287.

[10] Murphy MJ (1979) L-dopa induced dyskinesias in asymmetrical parkinsonism. Acta Neurol Latinoam, 25, 47-52.

[11] Marconi R, Lefebvre-Caparros D, Bonnet AM, Vidailhet M, Dubois B, \& Agid Y (1994) Levodopa-induced dyskinesias in Parkinson's disease phenomenology and pathophysiology. Mov Disord, 9(1), 2-12.

[12] Muenter MD, Sharpless NS, Tyce GM, \& Darley FL (1977) Patterns of dystonia ("I-D-I" and "D-I-D-") in response to 1-dopa therapy for Parkinson's disease. Mayo Clin Proc, 52, 163.

[13] LeWitt PA (1998) Conjugate eye deviations as dyskinesias induced by levodopa in Parkinson's disease. Mov Disord, 13, 731-734.

[14] Bozi M, \& Bhatia KP (2003) Paroxysmal exercise-induced dystonia as a presenting feature of young-onset Parkinson's disease. Mov Disord, 18(12), 1545-1547.

[15] Ahlskog JE, \& Muenter MD (2001) Frequency of levodoparelated dyskinesias and motor fluctuations as estimated from the cumulative literature. Mov Disord, 16, 448-458.

[16] Fabbrini G, Brotchie JM, Grandas F, Nomoto M, \& Goetz CG (2007) Levodopa-induced dyskinesias. Mov Disord, 22(10), 1379-1389.

[17] Vitale C, Pellecchia MT, Grossi D, Fragassi N, Cuomo T, Di Maio L, \& Barone P (2001) Unawareness of dyskinesias in Parkinson's and Huntington's diseases. Neurol Sci, 22, 105-106.

[18] Barbeau A (1980) High level levodopa therapy in severly akinetic Parkinsonism patients: Twelve years later. In: Rinne VK KM, Stamm G (ed) Parkinson's disease: Current progress, problems and management. Elsevier, Amsterdam, p 229-239.

[19] Parkinson study group (1996) Impact of deprenyl and tocopherol treatment on Parkinson's disease in DATATOP patients requiring levodopa. Parkinson study group. Ann Neurol, 39, 37-45.

[20] Poewe WH, Lees AJ, \& Stern GM (1986) Low-dose L-dopa therapy in Parkinson's disease: A 6-year follow-up study. Neurology, 36, 1528-1530.

[21] Blanchet PJ, Allard P, Gregoire L, Tardif F, \& Bedard PJ (1996) Risk factors for peak dose dyskinesia in 100 levodopa-treated parkinsonian patients. Can J Neurol Sci, 23, 189-193.

[22] Holloway RG, Shoulson I, Fahn S, Kieburtz K, Lang A, Marek K, McDermott M, Seibyl J, Weiner W, Musch B, Kamp C, Welsh M, Shinaman A, Pahwa R, Barclay L, Hubble J, LeWitt P, Miyasaki J, Suchowersky O, Stacy M, Russell DS, Ford B, Hammerstad J, Riley D, Standaert D, Wooten F, Factor S, Jankovic J, Atassi F, Kurlan R, Panisset M, Rajput A, Rodnitzky R, Shults C, Petsinger G, Waters C, Pfeiffer R, Biglan K, Borchert L, Montgomery A, Sutherland L, Weeks C, DeAngelis M, Sime E, Wood S, Pantella C, Harrigan M, Fussell B, Dillon S, Alexander-Brown B, Rainey P, Tennis M, Rost-Ruffner E, Brown D, Evans S, Berry D, Hall J, Shirley T, Dobson J, Fontaine D, Pfeiffer B, Brocht A, Bennett S, Daigneault S, Hodgeman K, O'Connell C, Ross T, Richard K, \& Watts A (2004) Pramipexole vs levodopa as initial treatment for Parkinson disease: A 4year randomized controlled trial. Arch Neurol, 61, 10441053. 
[23] Rascol O, Brooks DJ, Korczyn AD, De Deyn PP, Clarke CE, \& Lang AE (2000) A five-year study of the incidence of dyskinesia in patients with early Parkinson's disease who were treated with ropinirole or levodopa. 056 Study Group. N Engl J Med, 342, 1484-1491.

[24] López IC, Ruiz PJ, Del Pozo SV, \& Bernardos VS (2010) Motor complications in Parkinson's disease: Ten year follow-up study. Mov Disord, 25(16), 2735-2739.

[25] Hauser RA, Rascol O, Korczyn AD, Jon Stoessl A, Watts RL, Poewe W, De Deyn PP, \& Lang AE (2007) Ten year follow up of Parkinson's disease patients randomised to initial therapy with ropinirole or levodopa. Mov Disord, 22, 2409-2417.

[26] Hely MA, Morris JG, Traficante R, Reid WG, O'Sullivan DJ, \& Williamson PM (2005) Sydney Multicenter Study of Parkinson's disease: Non-L-dopa-responsive problems dominate at 15 years. Mov Disord, 20(2), 190-199.

[27] Rajput AH, Fenton ME, Birdi S, Macaulay R, George D, Rozdilsky B, Ang LC, Senthilselvan A, \& Hornykiewicz O (2002) Clinical-pathological study of levodopa complications. Mov Disord, 17(2), 289-296.

[28] Katzenschlager R, Head J, Schrag A, Ben-Shlomo Y, Evans A, \& Lees AJ; Parkinson's Disease Research Group of the United Kingdom (2008) Fourteen-year final report of the randomized PDRG-UK trial comparing three initial treatments in PD. Neurology, 71(7), 474-480.

[29] Van Gerpen JA (2006) Dopa-responsive dystonic camptocormia. Neurology, 66(11), 1779.

[30] Linasazoro G (2005) New ideas on the origin of L-dopainduced dyskinesias: age, genes and neural plasticity. Trends Pharmacol Sci, 26(8), 391-397.

[31] Rascol O, Brooks DJ, Korczyn AD, De Deyn PP, Clarke CE, \& Lang AE (2006) Development of dyskinesia in a 5 year trial of ropinirole and L-dopa. Mov Disord, 21, 18441850.

[32] Fahn S; and the Parkinson Study Group (2000) Does levodopa slow or hasten the rate of progression of Parkinson's disease? J Neurol, 252(Suppl 4), IV37-IV42.

[33] Grandas F, Galiano ML, \& Tabernero C (1999) Risk factors for levodopa-induced dyskinesias in Parkinson's disease. J Neurol, 246, 1127-1133.

[34] Kostić VS, Marinković J, Svetel M, Stefanova E, \& Przedborski S (2002) The effect of stage of Parkinson's disease at the onset of levodopa therapy on development of motor complications. Eur J Neurol, 9(1), 9-14.

[35] Onofrj M, Paci C, \& Thomas A (1998) Sudden appearance of invalidating dyskinesia-dystonia and off fluctuations after the introduction of levodopa in two dopaminomimetic drug naive patients with stage IV Parkinson's disease. J Neurol Neurosurg Psychiatry, 65, 605-606.

[36] Baas H (2000) Dyskinesia in Parkinson's disease. Pathophysiology and clinical risk factors. J Neurol, 247(Suppl 4), IV/12-16.

[37] Denny AP, \& Behari M (1999) Motor fluctuations in Parkinson's disease. J Neurol Sci, 165, 18-23.

[38] Kumar N, Van Gerpen JA, Bower JH, \& Ahlskog JE (2005) Levodopa-dyskinesia incidence by age of Parkinson's disease onset. Mov Disor, 20, 342-366.

[39] Ku S, \& Glass GA (2010) Age of Parkinson's disease onset as a predictor for the development of dyskinesia. Mov Disord, 25(9), 1177-1182.

[40] Kostic V, Przedborski S, Flaster E, \& Sternic N (1991) Early development of levodopa-induced dyskinesias and response fluctuations in young-onset Parkinson's disease. Neurology, 41, 202-205.
[41] Schrag A, Ben-Shlomo Y, Brown R, Marsden CD, \& Quinn N (1998) Young-onset Parkinson's disease revisited-clinical features, natural history, and mortality. Mov Disord, 13, 885894.

[42] Quinn N, Critchley P, \& Marsden CD (1987) Young onset Parkinson's disease. Mov Disord, 2, 73-79.

[43] Papapetropoulos S, Argyriou AA, Ellul J, \& Chroni E (2004) Comparison of motor fluctuations and L-dopainduced dyskinesias in patients with familial and sporadic Parkinson's disease. Eur J Neurol, 11(2), 115-119.

[44] Khan NL, Katzenschlager R, Watt H, Bhatia KP, Wood NW, Quinn N, \& Lees AJ (2004) Olfaction differentiates parkin disease from early-onset parkinsonism and Parkinson disease. Neurologu, 62(7), 1224-1226.

[45] Khan NL, Graham E, Critchley P, Schrag AE, Wood NW, Lees AJ, Bhatia KP, Quinn N (2005) Parkin disease: A phenotypic study of a large case series. Brain, 126, 1279-1292.

[46] Dekker M, Bonifati V, van Swieten J, Leenders N, Galjaard RJ, Snijders P, Horstink M, Heutink P, Oostra B, \& van Duijn C (2003) Clinical features and neuroimaging of PARK7linked parkinsonism. Mov Disord, 18(7), 751-757.

[47] Nishioka K, Kefi M, Jasinska-Myga B, Wider C, VilariñoGüell C, Ross OA, Heckman MG, Middleton LT, Ishihara-Paul L, Gibson RA, Amouri R, Ben Yahmed S, Ben Sassi S, Zouari M, El Euch G, Farrer MJ, \& Hentati F (2010) A comparative study of LRRK2, PINK1 and genetically undefined familial. Parkinson's disease, 81(4) 391-395.

[48] Khan NL, Jain S, Lynch JM, Pavese N, Abou-Sleiman P, Holton JL, Healy DG, Gilks WP, Sweeney MG, Ganguly M, Gibbons V, Gandhi S, Vaughan J, Eunson LH, Katzenschlager R, Gayton J, Lennox G, Revesz T, Nicholl D, Bhatia KP, Quinn N, Brooks D, Lees AJ, Davis MB, Piccini P, Singleton AB, \& Wood NW (2005) Mutations in the gene LRRK2 encoding dardarin (PARK8) cause familial Parkinson's disease: Clinical, pathological, olfactory and functional imaging and genetic data. Brain, 128, 2786-2796.

[49] Marras C, Schüle B, Munhoz RP, Rogaeva E, Langston JW, Kasten M, Meaney C, Klein C, Wadia PM, Lim SY, Chuang RS, Zadikof C, Steeves T, Prakash KM, de Bie RM, Adeli G, Thomsen T, Johansen KK, Teive HA, Asante A, Reginold W, \& Lang AE (2011) Phenotype in parkinsonian and nonparkinsonian LRRK2 G2019S mutation carriers. Neurolgy, 77(4), 325-333.

[50] Lohmann E, Thobois S, Lesage S, Broussolle E, du Montcel ST, Ribeiro MJ, Remy P, Pelissolo A, Dubois B, Mallet L, Pollak P, Agid Y, \& Brice A, French Parkinson's Disease Genetics Study Group (2009) A multidisciplinary study of patients with early-onset PD with and without parkin mutations. Neurology, 72(2), 110-116.

[51] Oliveri RL, Annesi G, Zappia M, Civitelli D, Montesanti R, Branca D, Nicoletti G, Spadafora P, Pasqua AA, Cittadella R, Andreoli V, Gambardella A, Aguglia U, \& Quattrone A (2001) Dopamine D2 receptor gene polymorphism and the risk of levodopa-induced dyskinesias in PD. Neurology 2, 53(7), 142530.

[52] Wang J, Liu ZL, \& Chen B (2001) Dopamine D5 receptor gene polymorphism and the risk of levodopa-induced motor fluctuations in patients with Parkinson's disease. Neurosci Lett, 308(1), 21-24.

[53] Bialecka M, Kurzawski M, Klodowska-Duda G, Opala G, Tan EK, \& Drozdzik M (2008) The association of functional catechol-O-methyltransferase haplotypes with risk of Parkinson's disease levodopa treatment response, and complications. Pharmacogenet Genomics, 18(9), 815-821. 
[54] Strong JA, Dalvi A, Revilla FJ, Sahay A, Samaha FJ, Welge JA, Gong J, Gartner M, Yue X, \& Yu L (2006) Genotype and smoking history affect risk of levodopa-induced dyskinesias in Parkinson's disease. Mov Disord, 21(5), 654-659.

[55] Molchadski I, Korczyn AD, Cohen OS, Katzav A, Nitzan Z, Chapman J, \& Hassin-Baer S (2001) The role of apolipoprotein E polymorphisms in levodopa-induced dyskinesia. Acta Neurol Scand, 123(2), 117-121.

[56] Foltynie T, Cheeran B, Williams-Gray CH, Edwards MJ, Schneider SA, Weinberger D, Rothwell JC, Barker RA, \& Bhatia KP (2009) BDNF val66met influences time to onset of levodopa induced dyskinesia in Parkinson's disease. J Neurol Neurosurg Psychiatr, 80(2), 141-144.

[57] Zappia M, Annesi G, Nicoletti G, Arabia G, Annesi F, Messina D, Pugliese P, Spadafora P, Tarantino P, Carrideo S, Civitelli D, De Marco EV, Cirò-Candiano IC, Gambardella A, \& Quattrone A (2005) Sex differences in clinical and genetic determinants of levodopa peak-dose dyskinesias in Parkinson disease: An exploratory study. Arch Neurol, 62(4), 601-605.

[58] Lyons KE, Hubble JP, Troster AI, Pahwa R, \& Koller WC (1998) Gender differences in Parkinson's disease. Clin Neuropharmacol, 21, 118-121.

[59] Sharma JC, Macnamara L, Hasoon M, Vassallo M, \& Ross I (2006) Cascade of levodopa dose and weight-related dyskinesia in Parkinson's disease (LD-WD-PD cascade). Parkinsonism Relat Disord, 12(8), 499-505.

[60] Kipfer S, Stephan MA, Schüpbach WM, Ballinari P, \& Kaelin-Lang A (2011) Resting tremor in Parkinson disease: A negative predictor of levodopa-induced dyskinesia. Arch Neurol, 8, 1037-1039.

[61] Manson AJ, Brown P, O'Sullivan JD, Asselman P, Buckwell D, Lees AJ (2000) An ambulatory dyskinesia monitor. J Neurol Neurosurg Psychiatry, 68, 196-201.

[62] Goetz CG, Damier P, Hicking C, Laska E, Müller T, Olanow CW, Rascol O, \& Russ H (2007) Sarizotan as a treatment for dyskinesias in Parkinson's disease: A double-blind placebocontrolled trial. Mov Disord, 22(2), 179-186.

[63] Colosimo C, Martínez-Martín P, Fabbrini G, Hauser RA, Merello M, Miyasaki J, Poewe W, Sampaio C, Rascol O, Stebbins GT, Schrag A, \& Goetz CG (2010) Task force report on scales to assess dyskinesia in Parkinson's disease critique and recommendations. Mov Disord, 25(9), 11311142.

[64] Goetz CG, Nutt JG, \& Stebbins GT (2008) The Unified Dyskinesia Rating Scale: Presentation and clinimetric profile. Mov Disord, 23(16), 2398-2403.

[65] Katzenschlager R, Schrag A, Evans A, Manson A, Carroll CB, Ottaviani D, Lees AJ, \& Hobart J (2007) Quantifying the impact of dyskinesias in PD: The PDYS-26: A patient-based outcome measure. Neurology, 69(6), 555-563.

[66] Olanow CW, Obeso JA (2000) Preventing levodopa-induced dyskinesias. Ann Neurol, 47, S167-S176; discussion S176S168.

[67] Lees AJ, \& Stern GM (1981) Sustained bromocriptine therapy in previously untreated patients with Parkinsons disease. J Neurol Neurosurg Psychiatry, 44, 1020-1023.

[68] Hauser RA, Schapira AH, Rascol O, Barone P, Mizuno Y, Salin L, Haaksma M, Juhel N, \& Poewe W et al. (2010) Randomized, doubleblind, multicenter evaluation of pramipexole extended release once daily in early Parkinson's disease. Mov Disord, 25, 2542-2549.

[69] Watts RL, Lyons KE, Pahwa R, Sethi K, Stern M, Hauser RA, Olanow W, Gray AM, Adams B, \& Earl NL; 228 Study Investigators (2010) Onset of dyskinesia with adjunct ropinirole prolonged-release or additional levodopa in early Parkinson's disease. Mov Disord, 25, 858-866.

[70] Bracco F, Battaglia A, Chouza C, Dupont E, Gershanik O, Marti Masso JF, \& Montastruc JL; PKDS009 Study Group (2004) The long-acting dopamine receptor agonist cabergoline in early Parkinson's disease: final results of a 5-year, double-blind, levodopa-controlled study. CNS Drugs, 18(11), 733-746.

[71] Fox SH, Katzenschlager R, Lim SY, Ravina B, Seppi K, Coelho M, Poewe W, Rascol O, Goetz CG, \& Sampaio C (2011) The Movement Disorder Society Evidence-Based Medicine Review Update: Treatments for the Motor Symptoms of Parkinson's Disease. Mov Disord, 26(Suppl), 3S2-3S4.

[72] Katzenschlager R, \& Lees AJ (2002) Treatment of Parkinson's disease: Levodopa as the first choice. J Neurol, 249(Suppl 2), II19-24.

[73] Chase TN (1998) The significance of continuous dopaminergic stimulation in the treatment of Parkinson's disease. Drugs, 55(Suppl 1), 1-9.

[74] Nutt JG (2007) Continuous dopaminergic stimulation: Is it the answer to the motor complications of Levodopa? Mov Disord, 22(1), 1-9.

[75] Hadj Tahar A, Grondin R, Grégoire L, Calon F, Di Paolo T, \& Bédard PJ (2003) New insights in Parkinson's disease therapy: can levodopa-induced dyskinesia ever be manageable. Adv Neurol, 91, 51-64.

[76] Fabbrini G, Di Stasio F, Bloise M, \& Berardelli A (2010) Soluble and controlled-release preparations of levodopa: Do we really need them? J Neurol, 257(Suppl 2), S292S297.

[77] Gottwald MD, \& Aminoff MJ (2011) Therapies for Dopaminergic-Induced Dyskinesia in Parkinson Disease. Ann Neur, 69, 919-927.

[78] Manson AJ, Turner K, \& Lees AJ (2002) Apomorphine monotherapy in the treatment of refractory motor complications of Parkinson's disease: Long-term follow-up study of 64 patients. Mov Disord, 17(6), 1235-1241.

[79] Katzenschlager R, Hughes A, Evans A, Manson AJ, Hoffman M, Swinn L, Watt H, Bhatia K, Quinn N, \& Lees AJ (2005) Continuous subcutaneous apomorphine therapy improves dyskinesias in Parkinson's disease: A prospective study using single-dose challenges. Mov Disord, 20(2), 151-157.

[80] Nilsson D, Nyholm D, \& Aquilonius SM (2001) Duodenal levodopa infusion in Parkinson's disease-long-term experience. Acta Neurol Scand, 104(6), 343-348.

[81] Antonini A, Bondiolotti G, Natuzzi F, \& Bareggi SR (2010) Levodopa and 3-OMD levels in Parkinson patients treated with Duodopa. Eur Neuropsychopharmacol, 20(10), 683687.

[82] Lees AJ (1993) Dopamine agonists in Parkinson's disease: A look at apomorphine. Fundam Clin Pharmacol, 7 , $1-128$.

[83] Devos D, French DUODOPA Study Group (2009) Patient profile, indications, efficacy and safety of duodenal levodopa infusion in advanced Parkinson's disease. Mov Disord, 24, 993-1000

[84] Antonini A, Isaias IU, Rodolfi G, Landi A, Natuzzi F, Siri C, Pezzoli G (2011) A 5-year prospective assessment of advanced Parkinson disease patients treated with subcutaneous apomorphine infusion or deep brain stimulation. J Neurol, 258(4), 579-585.

[85] Eggert K, Schrader C, Hahn M, Stamelou M, Rüssmann A, Dengler R, Oertel W, \& Odin P (2008) Continuous jejunal 
levodopa infusion in patients with advanced parkinson disease: practical aspects and outcome of motor and non-motor complications. Clin Neuropharmacol, 31(3), 151-166.

[86] Antonini A, Isaias IU, Canesi M, Zibetti M, Mancini F, Manfredi L, Dal Fante M, Lopiano L, \& Pezzoli G (2007) Duodenal levodopa infusion for advanced Parkinson's disease: 12-month treatment outcome. Mov Disord, 22(8), 1145-1149.

[87] Urban PP, Wellach I, Faiss S, Layer P, Rosenkranz T, Knop K, \& Weis J (2010) Subacute axonal neuropathy in Parkinson's disease with cobalamin and vitamin B6 deficiency under duodopa therapy. Mov Disord, 25(11), 17481752.

[88] Cenci MA, Ohlin KE, \& Odin P (2011) Current options and future possibilities for the treatment of dyskinesia and motor fluctuations in Parkinson's disease. CNS Neurol Disord Drug Targets, 10, 670-684.

[89] Rascol O (2000) Medical treatment of levodopa-induced dyskinesias. Ann Neurol, 47, S179-S188.

[90] Verhagen Metman L, Del Dotto P, van den Munckhof P, Fang J, Mouradian MM, \& Chase TN (1998) Amantadine as treatment for dyskinesias and motor fluctuations in Parkinson's disease. Neurology, 50, 1323-1326.

[91] Snow BJ, Macdonald L, McAuley D, \& Wallis W (2000) The effect of amantadine on levodopa-induced dyskinesias in Parkinson's disease: A double-blind, placebo-controlled study. Clin Neuropharmacol, 23(2), 82-85.

[92] da Silva-Júnior FP, Braga-Neto P, Sueli Monte F, \& de Bruin VM (2005) Amantadine reduces the duration of levodopainduced dyskinesia: A randomized, double-blind, placebocontrolled study. Parkinsonism Relat Disord, 11(7), 449452.

[93] Wolf E, Seppi K, Katzenschlager R, Hochschorner G, Ransmayr G, Schwingenschuh P, Ott E, Kloiber I, Haubenberger D, Auff E, \& Poewe W (2010) Long-term antidyskinetic efficacy of amantadine in Parkinson's disease. Mov Disord, 25(10), 1357-1363.

[94] Del Dotto P, Pavese N, Gambaccini G, Bernardini S, Metman LV, Chase TN, \& Bonuccelli U (2001) Intravenous amantadine improves levadopa-induced dyskinesias: An acute double-blind placebo-controlled study. Mov Disord, 16(3), 515-520.

[95] Crosby NJ, Deane KH, Clarke CE (2003) Amantadine for dyskinesia in Parkinson's disease. Cochrane Database Syst Rev, CD003467.

[96] Sawada H, Oeda T, Kuno S, Nomoto M, Yamamoto K, Yamamoto M, Hisanaga K, Kawamura T; Amantadine Study Group (2010) Amantadine for dyskinesias in Parkinson's disease: A randomized controlled trial. PLoS One, 5(12), 15298.

[97] Durif F, Debilly B, Galitzky M, Morand D, Viallet F, Borg M, Thobois S, Broussolle E, \& Rascol O (2004) Clozapine improves dyskinesias in Parkinson disease: a double-blind, placebo-controlled study. Neurology, 62(3), 381-388.

[98] Bennett JP Jr, Landow ER, Dietrich S, Schuh LA (1994) Suppression of dyskinesias in advanced Parkinson's disease: moderate daily clozapine doses provide long-term dyskinesia reduction. Mov Disord, 9(4), 409-414.

[99] Pierelli F, Adipietro A, Soldati G, Fattapposta F, Pozzessere G, \& Scoppetta C (1998) Low dosage clozapine effects on L-dopa induced dyskinesias in parkinsonian patients. Acta Neurol Scand, 97(5), 295-299.

[100] Manson AJ, Schrag A, \& Lees AJ (2000) Low-dose olanzapine for levodopa induced dyskinesias. Neurology, 55, 795-799.
[101] Katzenschlager R, Manson AJ, Evans A, Watt H, Lees AJ (2004) Low dose quetiapine for drug induced dyskinesias in Parkinson's disease: A double blind cross over study. J Neurol Neurosurg Psychiatry, 5(2), 295-297.

[102] Lyons KE, \& Pahwa R (2006) Efficacy and tolerability of levetiracetam in Parkinson disease patients with levodopainduced dyskinesia. Clin Neuropharmacol, 29(3), 148153.

[103] Stathis P, Konitsiotis S, Tagaris G, \& Peterson D; VALID-PD Study Group (2010) Levetiracetam for the management of levodopa-induced dyskinesias in Parkinson's disease. Mov Disord, 26(2), 264-270.

[104] Hauser RA, Cantillon M, Pourcher E, Micheli F, Mok V, Onofrj M, Huyck S, \& Wolski K (2011) Preladenant in patients with Parkinson's disease and motor fluctuations: A phase 2, double-blind, randomised trial. Lancet Neurol, 10(3), 221-229.

[105] Schapira AH (2010) Safinamide in the treatment of Parkinson's disease. Expert Opin Pharmacother, 11(13), 2261-2268.

[106] Savola JM, Hill M, Engstrom M, Merivuori H, Wurster S, McGuire SG, Fox SH, Crossman AR, \& Brotchie JM (2003) Fipamezole (JP-1730) is a potent alpha2 adrenergic receptor antagonist that reduces levodopa-induced dyskinesia in the MPTP-lesioned primate model of Parkinson's disease. Mov Disord, 18(8), 872-883.

[107] Rascol O, Arnulf I, Peyro-Saint Paul H, Brefel-Courbon C, Vidailhet M, Thalamas C, Bonnet AM, Descombes S, Bejjani B, Fabre N, Montastruc JL, \& Agid Y (2001) Idazoxan, an alpha-2 antagonist, and L-DOPA-induced dyskinesias in patients with Parkinson's disease. Mov Disord, 16(4), 708713.

[108] Eggert K, Squillacote D, Barone P, Dodel R, Katzenschlager R, Emre M, Lees AJ, Rascol O, Poewe W, Tolosa E, Trenkwalder C, Onofrj M, Stocchi F, Nappi G, Kostic V, Potic J, Ruzicka E, \& Oertel W (2010) German Competence Network on Parkinson's Disease. Safety and efficacy of perampanel in advanced Parkinson's disease: A randomized, placebo-controlled study. Mov Disord, 25(7) 896-890.

[109] Bronzova J, Sampaio C, Hauser RA, Lang AE, Rascol O, Theeuwes A, van de Witte SV, \& van Scharrenburg G (2010) Bruegel Study Group Double-blind study of pardoprunox, a new partial dopamine agonist, in early Parkinson's disease. Mov Disord, 25(6), 738-746.

[110] Quik M, Huang LZ, Parameswaran N, Bordia T, Campos C, \& Perez XA (2009) Multiples role for nicotine in Parkinson's disease. Biochem Pharmacol, 78, 677-685.

[111] Berg D, Godau J, Trenkwalder C, Eggert K, Csoti I, Storch A, Gasparini F, Hariry S, Johns D, \& a Gomez-Mancilla B (2010) AFQ056 treatment of severe levodopa-induced dyskinesias: proof of concept study. Mov Disord, 25(Supp12), S290.

[112] Grégoire L, Morin N, Ouattara B, Gasparini F, Bilbe G, Johns D, Vranesic I, Sahasranaman S, Gomez-Mancilla B, \& Di Paolo T (2011) The acute anti parkinsonian and anti dyskinetic effect of AFQ056, a novel metabotropic glutamate receptor type 5 antagonist, in L-Dopa-treated parkinsonian monkeys. Parkinsonism Relat Disord, 17(4), 270-276.

[113] Bronstein JM, Tagliati M, Alterman RL, Lozano AM, Volkmann J, Stefani A, Horak FB, Okun MS, Foote KD, Krack P, Pahwa R, Henderson JM, Hariz MI, Bakay RA, Rezai A, Marks WJ Jr, Moro E, Vitek JL, Weaver FM, Gross RE, \& DeLong MR (2011) Deep brain stimulation for Parkinson disease: An expert consensus and review of key issues. Arch Neurol, 68(2), 165. 
[114] Sankar T, \& Lozano AM (2011) Surgical approach to 1-dopainduced dyskinesias. Int Rev Neurobiol, 98, 151-171.

[115] Pilitsis JG, Metman LV, Toleikis JR, Hughes LE, Sani SB, \& Bakay RA (2008) Factors involved in long-term efficacy of deep brain stimulation of the thalamus for essential tremor. J Neurosurg, 109(4), 640-646.

[116] Krach P, Batin A, Van Blercom N, Chabardas S, Fraix V, Ardouin C, Limousin PD, Benazzouz A, LeBas JF, Benabid AL, \& Pollak P (2003) Five year follow-up of bilateral stimulation of the subthalamic nucleus in advanced Parkinsin's disease. N Enngl J Med, 349, 1923-1934.

[117] Volkmann J, Allert N, Voges J, Sturm V, Schnitzler A, \& Freund HJ (2004) Long-term results of bilateral pallidal stimulation in Parkinson's disease. Ann Neurol, 55(6), 871-875.

[118] Follett KA, Weaver FM, Stern M, Hur K, Harris CL, Luo P, Marks WJ Jr, Rothlind J, Sagher O, Moy C, Pahwa R, Burchiel K, Hogarth P, Lai EC, Duda JE, Holloway K, Samii A, Horn S, Bronstein JM, Stoner G, Starr PA, Simpson R, Baltuch G, De Salles A, Huang GD, \& Reda DJ; CSP 468 Study Group (2010) Pallidal versus subthalamic deep-brain stimulation for Parkinson's disease. N Engl J Med, 362(22), 2077-2091.

[119] Weaver FM, Follett K, Stern M, Hur K, Harris C, Marks WJ Jr, Rothlind J, Sagher O, Reda D, Moy CS, Pahwa R, Burchiel K, Hogarth P, Lai EC, Duda JE, Holloway K, Samii A, Horn S, Bronstein J, Stoner G, Heemskerk J, \& Huang GD; CSP 468 Study Group (2009) Bilateral deep brain stimulation vs best medical therapy for patients with advanced Parkinson disease: A randomized controlled trial. JAMA, 301(1), 63-73.

[120] Rascol O, Lozano A, Stern M, \& Poewe W (2011) Milestones in Parkinson's disease therapeutics. Mov Disord, 26(6), 1072-1082.

[121] Hamani C, Neimat J, \& Lozano AM (2006) Deep brain stimulation for the treatment of Parkinson's disease. J Neural Transm Suppl, 70, 393-399.

[122] Contarino MF, Daniele A, Sibilia AH, Romito LM, Bentivoglio AR, Gainotti G, \& Albanese A (2007) Cognitive outcome 5 years after bilateral chronic stimulation of subthalamic nucleus in patients with Parkinson's disease. J Neurol Neurosurg Psychiatry, 78(3), 248-252.
[123] Saint-Cyr JA, Trépanier LL, Kumar R, Lozano AM, \& Lang AE (2000) Neuropsychological consequences of chronic bilateral stimulation of the subthalamic nucleus in Parkinson's disease. Brain, 123, 2091-2108.

[124] Hälbig TD, Tse W, Frisina PG, Baker BR, Hollander E, Shapiro H, Tagliati M, Koller WC, \& Olanow CW (2009) Subthalamic deep brain stimulation and impulse control in Parkinson's disease. Eur J Neurol, 16(4), 493-497.

[125] Smeding HM, Speelman JD, Koning-Haanstra M, Schuurman PR, Nijssen P, van Laar T, \& Schmand B (2006) Neuropsychological effects of bilateral STN stimulation in Parkinson disease: A controlled study. Neurology, 66(12), 1830-1836.

[126] Koch G (2010) rTMS effects on levodopa induced dyskinesias in Parkinson's disease patients: Searching for effectiv cortical targets Restorative. Neurology and Neuroscience, 28, 561-568.

[127] Chapuis S, Ouchchane L, Metz O, Gerbaud L, \& Durif F (2005) Impact of the motor complications of Parkinson's disease on the quality of life. Mov Disord, 20, 224-223.

[128] Steiger MJ, Quinn NP, \& Marsden CD (1991) Sickness due to levodopa-induced neck dyskinesias in Parkinson's disease [letter]. Mov Disord, 6, 91-92.

[129] Damiano AM MM, William MK, SnyderCF CF, LeWitt PA, \& Richter RR (2000) Evaluation of a measurement strategy for Parkinson's disease: Patient health-related quality of life. Quality of Life Research, 9, 87-100.

[130] Siderowf A, Ravina B, \& Glick HA (2002) Preferencebased quality-of-life in patients with Parkinson's disease. Neurology, 59, 103-108.

[131] Pechevis M, \& Vieregge P (2001) Direct and indirect costs of Parkinson's Disease and L-dopa induced dyskinesias: A prospective European study. Parkinsonism Relat Disord, 7(suppl), 106.

[132] Marras C, Lang A, Krahn M, Tomlinson G, \& Naglie G (2004) Quality of life in early Parkinson's disease: Impact of dyskinesias and motor fluctuations. Mov Disord, 19, 2228.

[133] Amanzio M, Monteverdi S, Giordano A, Soliveri P, Filippi P, \& Geminiani G (2010) Impaired awareness of movement disorders in Parkinson's disease. Brain Cogn, 72(3), 337 346. 